\title{
Immunological and molecular diagnosis of cysticercosis
}

\author{
Silvia Rodriguez ${ }^{1}$, Patricia Wilkins ${ }^{2}$, Pierre Dorny ${ }^{3}$
}

${ }^{1}$ Instituto Nacional de Ciencias Neurológicas, Lima, Peru, ${ }^{2}$ Division of Parasitic Diseases \& Malaria, Centers for Disease Control \& Prevention, Atlanta, GA, USA, ${ }^{3}$ Department of Biomedical Sciences, Institute of Tropical Medicine, Antwerp, Belgium

Cysticercosis, the infection with the larval stage of Taenia solium, is a cause of neurological symptoms including seizures, affecting the quality of life of patients and their families. Diagnosis focuses on brain imaging and serological tests are mostly used as confirmatory tools. Most cases, however, occur in poor endemic areas, where both kinds of diagnostic tools are poorly available. Development of point of care diagnostic tests is one of the most important priorities for cysticercosis researches today. The ideal point of care test would require detection of viable cysticercosis and hopefully identify cases with severe or progressive forms of neurocysticercosis, leading to referral of the patient for specialized medical attention. This manuscript describes the evolution of the serological diagnosis of cysticercosis over time, and the characteristics of the most common currently available tools, their advantages and disadvantages, and their potential use in future diagnostic tests.

Keywords: Cysticercosis, Neurocysticercosis, Immunodiagnosis, Antibody, Antigen, Serology, Taenia solium, Western blot

\section{Introduction}

The varied clinical presentations of neurocysticercosis (NCC) result from a series of factors, which include the number, stage, size, and location of parasites in the nervous system of the human host, factors which also influence case management and prognosis. In this context, the utility of immunodiagnosis as a tool on which to base clinical decisions by itself is quite limited. Diagnosis and characterization of human NCC should be based on a brain imaging examination to observe the characteristics of the lesions, accompanied by a serological test result to confirm the etiology. In the best possible scenario, the immunological test should not only be highly sensitive and highly specific for etiological confirmation but also be able to discriminate infections with living parasites from inactive infections, and correlate the characteristics of the infection with parasite load, for patient management and follow-up. A century of serological assay development for Taenia solium cysticercosis has provided some tests which fulfill several of the above requirements, albeit the ideal assay has yet to be developed.

This review will discuss most of the available immunodiagnostic tests for cysticercosis, focusing on the lentil lectin glycoprotein enzyme-linked immunoelectrotransfer

Correspondence to: Silvia Rodriguez, Infectious Diseases, Instituto Nacional de Ciencias Neurológicas, Jr. Anchash 1271, Lima 1, Peru. Email: silvia@ peruresearch.org blot (LLGP-EITB) assay as the test of choice, the advantages and disadvantages of antigen and antibody detection, as well as the importance of the selection of the type of sample to be processed. We will also stress the importance of evaluating new diagnostic assays with well-defined sets of sera reflecting the entire spectrum of NCC infection (active/inactive, intra/ extraparenchymal, diverse numbers of lesions including viable or degenerating cysts for single-lesion cases, cases from diverse geographic areas).

\section{Antibody Detection Tests for Cysticercosis}

Early in the twentieth century, the laboratory diagnosis of tissue parasites was limited to nonspecific findings of increased white cell counts, strongly valuing the presence of increased eosinophil numbers. ${ }^{1,2}$ The first serological assays for parasitic infections were complement precipitation and fixation techniques. In 1909, Weinberg used complement fixation with cystic fluid from cysticerci to demonstrate specific antibodies in the sera of a group of cysticercotic pigs. $^{3}$ This test became known as 'Weinberg's reaction' and was used until a few decades ago. ${ }^{4-6}$ In 1911, Arthur Moses reported the use of an aqueous cysticercal extract to demonstrate the presence of antibodies in the serum of three patients with subcutaneous cysticercosis and in the cerebrospinal fluid (CSF) of a patient with cysticercosis encephalitis, thus demonstrating for the first 
time, the presence of anti-cysticercal antibodies in CSF. ${ }^{1,7}$

In the following decades, many attempts to develop better diagnostic tests focused on indirect, antibody detection assays. Antibody detection does not distinguish active from inactive infections, and is not useful to monitor changes over short periods; ${ }^{8}$ however, its diagnostic efficacy is much higher than that of antigen detection assays. ${ }^{9,10}$ These indirect assays include indirect hemagglutination, immunoelectrophoresis, double immunediffusion, precipitation, indirect immunofluorescence, and skin reaction, among others, ${ }^{11-17}$ and are comprehensively described in Flisser et al. ${ }^{18}$ By 1971, Engvall and Perlmann described the enzymelinked immunosorbent assay (ELISA) technique. ${ }^{19}$ The ELISA is a quite simple technique, is sensitive, quantitative, and can process many samples at the same time, thus it soon became the most frequently used antibody detection assay (ELISA-Ab). It was initially applied in 1978 for the diagnosis of NCC by Arambulo et al. in cases with high suspicion for NCC, reporting better sensitivity than the indirect hemagglutination, the test in use at that time. ${ }^{20}$ Coker-Vann et al. then applied the ELISA technique to detect $T$. solium antibodies in epidemiological studies. ${ }^{21}$ Many other laboratories adopted the ELISA-Ab with varied sensitivities according to the antigen and serum panels used. It was evident, however, that the ELISA performed better than the previous techniques. Initial assays used crude metacestode antigens. ${ }^{21-24}$ Better results were obtained using cystic fluid as the antigens, but not with membrane or scolex antigens. ${ }^{25}$

Unfortunately, a series of factors affected the diagnostic capacity of these early techniques: the sensitivity and specificity of each technique, the difficulties in defining appropriate reference sera sets, and the use of crude or minimally purified antigens, leading to non-specific reactions mainly with echinococcosis, schistosomiasis, angiostrongyliasis, sparganosis, and fasciolasis. ${ }^{22,26-29}$ Case definitions and reference serum batteries were greatly improved with the advent of computed tomography (CT) in 1977 and magnetic resonance imaging in 1986. Cases of NCC could then be differentiated in terms of number of lesions, stage, and location (intraparenchymal or extraparenchymal NCC), variables, which strongly influence the host's humoral immune response. ${ }^{30}$

Antigen characterization became then the objective of researchers looking for improved serological tests. One of the more studied antigens was antigen B, described by Flisser et al. in 1980 as the antigen more frequently recognized by sera from NCC-infected patients, ${ }^{31}$ producing a strong antibody response. ${ }^{32-34}$ Use of antigen B in an antibody detecting ELISA in serum $^{35}$ as well as in CSF, did not demonstrate much advantage over other antigen sources. ${ }^{36,37}$ Grogl et al. in 1985 characterized a series of 37 antigenic proteins from the total metacestode extract as suitable candidates for immunodiagnosis, ${ }^{38}$ using for the first time the EITB technique, originally used for immunodiagnosis of schistosomiasis. ${ }^{38,39}$ A series of other antigens were then purified using chromatographic techniques and were reported to perform with high sensitivity in cysticercosis immunodiagnosis. ${ }^{27,28,40-43}$

In 1989, the EITB (also known as western blot or immunoblot) using the LLGP fraction was developed and quickly became the assay of choice for serodiagnosis. The LLGP-EITB combines the specificity of using antigens previously purified by chromatography plus the resolution capacity of polyacrylamide gel electrophoresis with sodium dodecyl sulfate coupled with the sensitivity of enzyme-based immunodetection. Seven antigenic glycoproteins (GP) were isolated from a total metacestode homogenate and then purified using lentil-lectin chromatography, namely GP50, GP42-39, GP24, GP21, GP18, GP14, and GP13, where the numbers referred to their molecular mass in kilodaltons (Fig. 1). The presence of any one of the seven antibody bands defines a positive test, with an initial sensitivity and specificity reported to be 98 and $100 \%$, respectively. No crossreactions were found in 376 sera from 18 heterologous infections. ${ }^{44}$ Further comparative testing demonstrated the superiority of the LLGP-EITB over ELISA for the diagnosis of human ${ }^{10,45-48}$ and porcine cysticercosis. ${ }^{49}$

Antibody-detecting techniques in general do not have the capacity to distinguish between exposure, inactive infection and active infection, have a low positive predictive value in cases with viable cysticercosis (due to positive antibody reactions in individuals with calcified cysticerci and a high background of seroprevalence in the general population in endemic areas), and have low sensitivity in cases with a single brain lesion. ${ }^{50,51}$ Even though the LLGPEITB is currently considered the test of choice for serodiagnosis of cysticercosis, it has its own drawbacks, which include the source of antigen (the method requires fresh cysts from infected pigs), and is also a complicated procedure. Thus, more recent research efforts have focused on the characterization and synthesis or production of recombinant forms of the seven LLGP diagnostic antigens to produce simpler and more reproducible assays.

Molecular studies showed that the seven LLGP diagnostic antigens comprise three protein families: GP50, T24/T42, and the $8 \mathrm{kDa}$ family. ${ }^{52-54} \mathrm{GP50}$ is the largest of the LLGP antigens. ${ }^{53}$ Although no defined cross-reactions have been reported to any of the LLGPs, a 'bogus' band can appear slightly above GP50 and generates a problem of interpretation when reading the strips, ${ }^{44}$ even in patients without evidence 


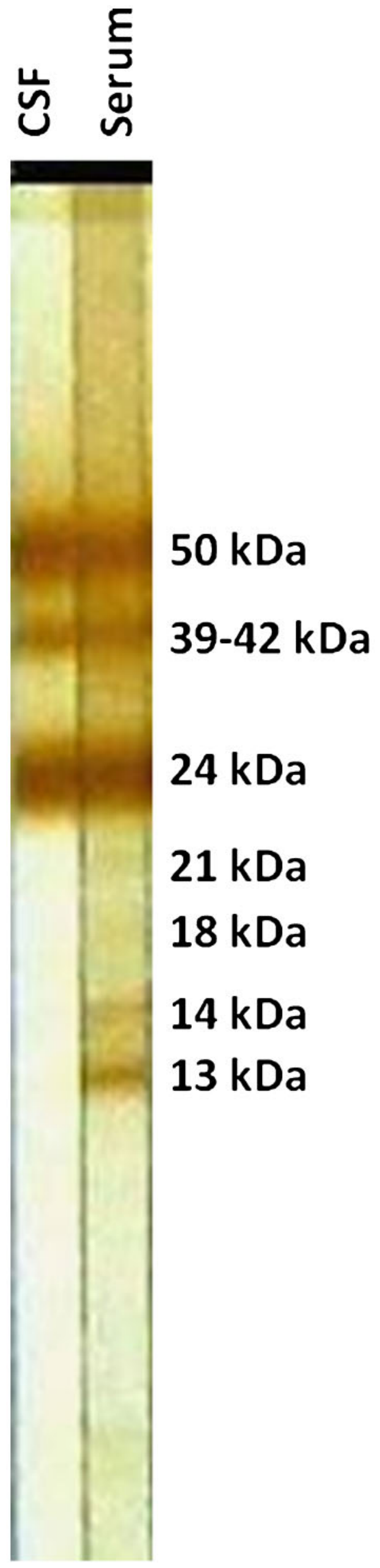

Figure 1 Lentil lectin glycoprotein enzyme-linked immunoelectrotransfer blot (LLGP-EITB) showing the molecular weights of the seven diagnostic bands, and the difference between antibody levels in paired cerebrospinal fluid (CSF) and serum samples from the same individual.

of exposure to $T$. solium, thus its presence as a single reactive band should be taken with caution. ${ }^{55,56}$ GP50 and GP39-42 are the more immunodominant antigens, inducing vigorous IgG-response, ${ }^{57}$ both are membrane proteins. Studies have demonstrated that GP24 is a monomeric form and GP42-39 is a homodimeric form of the same protein. ${ }^{53,58}$ Both have already been produced as recombinants (rGP50 and $\mathrm{rT} 24 \mathrm{H}$ ) in an eukaryotic expression system, with good diagnostic performances in EITB and in ELISA, ${ }^{53,54,59}$ as well as in a novel proprietary technique, the QuickELISA. ${ }^{60}$ In general, rT24H performs slightly better than rGP50, but neither antigen alone reaches the sensitivity and specificity of the combined native LLGP set.

The remaining LLGPs, of lower molecular weights, correspond to a complex group of $8 \mathrm{kDa}$ peptides, which can be found alone or in oligomeric structures, which have molecular masses as large as $42 \mathrm{kDa} .{ }^{61}$ Similar antigens have been reported in other taeniid cestodes, such as T. hydatigena, T. multiceps, and Echinococcus granulosus. ${ }^{62-65}$ These small peptides have been described as excretory/secretory (E/S) products and have been associated with immune evasion functions. ${ }^{61,66}$ In some cases, the immunogenic activity of synthetic and native forms correlate well and thus do not seem to depend on secondary structure resulting from post-translational modifications such as a glycosylation; ${ }^{67,68}$ in some cases, there seems to be a component of the immune response that depends on conformational epitopes. ${ }^{69}$ The presence of low molecular bands in the LLGP-EITB is rarely seen in absence of reactivity to the higher LLGP antigens and seems to be associated with more severe infections. The use of these smaller $8 \mathrm{kDa}$ LLGP peptides as serodiagnostic tools has been proposed because of their capacity to discriminate between active and inactive infections, ${ }^{70,71}$ and their availability as synthetic peptide. TsRS1 and Ts18var1 are two peptides in this family, with reasonable sensitivity and specificity in ELISA, which greatly improve when used in EITB format. They however, show lower diagnostic utility when compared to the native forms to detect single lesion cases ${ }^{68}$ Other diagnostic candidates in the $8 \mathrm{kDa}$ family have been expressed and produced as recombinant proteins including Ts $8 \mathrm{~B} 1, \mathrm{Ts} 8 \mathrm{~B} 2$, and Ts8B3. Among these, the Ts $8 \mathrm{~B} 2$ antigen was better able to discriminate between cases of active and inactive $\mathrm{NCC},{ }^{72}$ although some cross-reactions with echinococcosis and schistosomiasis were observed. ${ }^{73}$ 
Splitting the Ts8B2 in smaller synthetic peptides greatly affected the antigen performance. ${ }^{69}$ Yang et al. described a $10 \mathrm{kDa}$ antigen from cyst fluid, also belonging to the $8 \mathrm{kDa}$ family, reacting mainly to IgG4 and IgG1. ${ }^{74}$ This $10 \mathrm{kDa}$ antigen was also produced in recombinant form and showed a good performance to differentiate active from inactive NCC. ${ }^{71}$

Other native antigens under research include parasite proteases. In 2005, Baig et al. described a protease from the $T$. solium metacestode with Lcathepsin activity and able to degrade IgG (suggesting a role in immune evasion) ${ }^{75} \mathrm{~A}$ second similar protease was also identified by a different group soon after. This protease, produced in recombinant form, had antigenic activity recognized by sera from patients with NCC. ${ }^{76}$ Two other protease fractions highly abundant in cystic fluid have been isolated and evaluated in ELISA and EITB with promising results, and in dot blot form, with lower sensitivity, albeit higher specificity. ${ }^{77,78}$

Synthetic peptide production is appealing for its ease of production and inherent reproducibility. However, to date no synthetic peptide has performed at the level of native antigens for diagnostic purposes. ${ }^{61,67,79-81}$ A possible alternative is to use more than one synthetic peptide in the same assay, ${ }^{82}$ as in the multiantigen print immunoassay, in which several recombinant or synthetic antigens are printed at different positions along a single strip and thus obviating the need for electrophoretic separation. ${ }^{83}$ Recombinant proteins perform better than synthetic peptides, most likely because part of the response is directed towards conformational epitopes. ${ }^{69}$ Recombinants to several of the seven LLGP described by Tsang et al., have shown better results than related synthetic peptides in EITB as well as in ELISA. ${ }^{53,54,60,84}$ A recently reported recombinant protein, Tsolp27, promisingly detected all cases, but specimens from only 13 cases were tested (Table 1). ${ }^{85}$

Other attempts to develop immunodiagnostic tests include the lymphocyte transformation test (LTT) described by Prasad et al., in 2008, who found 94\% of sensitivity and $96 \%$ of specificity. This assay requires lymphocyte separation, long incubation time, and a radioactive developer. The authors proposed their use in patients with a single brain lesion but further evaluations are still missing. ${ }^{86}$ LTT seems to offer a good alternative to evaluate a host's exposure to a given antigen but will likely not differentiate active from inactive cases because the assay is based on the presence of memory $\mathrm{T}$ cells. ${ }^{87}$

Phage display peptide selection was reported as early as in $1999 .{ }^{88}$ Almost 10 years later, Hell et al. produced a synthetic peptide against a scolex antigen with this technology. ${ }^{89}$ Initial promising results have been reported for two other peptides produced with this technique. ${ }^{90,91}$ As proposed by EsquivelVelazquez et al., in 2011, new tools like phage display peptide selection, production of synthetic, and recombinant antigens, could permit us to shorten the path to identify specific antigens capable to distinguish not only the stages of the parasite, but also exposure from viable and non-viable infection. ${ }^{92}$ In this way, a good alternative to distinguish exposure from infection could be the use of oncospheral antigens, which to date have mostly been used as vaccine candidates. The $8 \mathrm{kDa}$ antigens seem to be promising candidates to distinguish viable from nonviable NCC; however, the sensitivity of these assays needs improving..$^{70,71,73,93}$

\section{Advantages and disadvantages of antibody detection in cysticercosis}

Sound use of serological assays goes beyond the choice of a test and greatly depends on appropriate interpretation of results in the context of a given patient or a given population. Antibody detection with a sensitive and specific assay is the best alternative to diagnose whether somebody has been infected with cysticerci. ${ }^{9}, 10$ Antibody detection however does not discriminate between active and inactive infections and thus its clinical utility is restricted to etiological confirmation (although strong antibody reactions suggest severe infections ${ }^{94-96}$ and, unlike total $\mathrm{IgG}^{8}{ }^{8} \mathrm{IgG} 4$ detection can be associated with active infection ${ }^{97,98}$ as well as provide a good monitoring marker ${ }^{99,100}$ for cure).

In field conditions, antibody seroprevalence overestimates the actual prevalence of infection because persons with antibodies from exposure and from past infections are also detected. Even more, there is evidence that almost $40 \%$ of the positive results in an endemic area are produced by transient antibodies, which become undetectable within 1 year. ${ }^{101}$ Detection of parasite specific antibodies in asymptomatic individuals has limited clinical use. Antibody prevalence, however, can provide valuable information on exposure to the parasite, transmission dynamics, risk factors, and incidence calculations, thus it should still be considered a tool for control programs. ${ }^{47,102-107}$

In summary, a positive antibody test associated with a suggestive brain image strongly supports the diagnosis of NCC, while in endemic regions where no CT or magnetic resonance imaging is available, a positive antibody test should be mainly used to refer patients with neurological symptoms to a more equipped center for imaging diagnosis and etiological case management.

\section{Appropriate samples for antibody detection}

Selection of a particular type of sample depends on the available test and antigen. In a study of Sahu 
et al., serum performed better than CSF when using $\mathrm{E} / \mathrm{S}$ antigens but there were no differences when using somatic antigens. ${ }^{108}$ In general, the evidence suggests that with properly specific assays, serum performs better than CSF for antibody detection. ${ }^{10,46,48,50,109,110}$ Some authors note that the simultaneous use of both samples can provide important information on the infection status of the patient. ${ }^{111}$

Tests with less specificity and/or less purified antigens give better results with CSF due to the lower frequency of cross-reacting antibodies in CSF. However, a lumbar puncture to obtain CSF is, however, painful and invasive, and poorly accepted by patients. It is important to note that CSF taken from the ventricles (during surgery or through a shunt) or cisterns (cisternal puncture) can differ from samples collected by lumbar puncture in terms of protein concentration. A gradient along the neuroaxis has been described. ${ }^{112,113}$ Also, there may be intrathecally produced antigens in the CSF, particularly during antiparasitic treatment. ${ }^{114-119}$

Venipuncture is the preferred collection method for clinical laboratory studies; however, blood can be also collected by finger prick on filter paper. This procedure is quite advantageous for sample storage and transport and is quite well accepted by the population and can be of great use in field studies or whenever venipuncture is not possible. The LLGP-EITB

Table 1 Antigens used to diagnose NCC by antibody capture

\begin{tabular}{|c|c|c|c|c|c|c|c|}
\hline Test & Type of antigen & $\begin{array}{l}\text { Sensitivity } \\
\text { (1 lesion) }\end{array}$ & $\begin{array}{l}\text { Sensitivity } \\
\text { (>2 } \\
\text { lesions) }\end{array}$ & Specificity & $\begin{array}{l}\text { Cross- } \\
\text { reactions }\end{array}$ & $\begin{array}{l}\text { CSF better } \\
\text { than serum }\end{array}$ & References \\
\hline LLGP-EITB & $\begin{array}{l}\text { Native semi-purified } \\
\text { from whole cyst }\end{array}$ & $\sim 50 \%$ & $98 \%$ & $100 \%$ & No & No & $\begin{array}{l}{[10,44,48,50,} \\
51,109,179]\end{array}$ \\
\hline rGP50-EITB & $\begin{array}{l}\text { Recombinant } \\
\text { from } 50 \mathrm{kDa}\end{array}$ & $N / E$ & $90 \% *$ & $100 \%$ & $\mathrm{~N} / \mathrm{E}$ & $\mathrm{N} / \mathrm{E}$ & {$[53]$} \\
\hline rGP50-ELISA & $\begin{array}{l}\text { Recombinant } \\
\text { from } 50 \mathrm{kDa}\end{array}$ & $\mathrm{N} / \mathrm{E}$ & $95 \% *$ & $94 \% *$ & No & Yes & {$[59]$} \\
\hline $\begin{array}{l}\text { rGP50- } \\
\text { QuickELISA }\end{array}$ & $\begin{array}{l}\text { Recombinant } \\
\text { from } 50 \mathrm{kDa}\end{array}$ & $42 \% *$ & $94 \% *$ & $99 \% *$ & No & $N / E$ & {$[60]$} \\
\hline rGP50-MAPIA & $\begin{array}{l}\text { Recombinant } \\
\text { from } 50 \mathrm{kDa}\end{array}$ & $53 \%$ & $93 \%$ & $100 \%$ & No & $N / E$ & [83] \\
\hline rT24-EITB & $\begin{array}{l}\text { Recombinant } \\
\text { from } 24 \mathrm{kDa}\end{array}$ & $63 \% *$ & $94 \% *$ & $98 \%$ & No & $N / E$ & {$[54]$} \\
\hline rT24-QuickELISA & $\begin{array}{l}\text { Recombinant } \\
\text { from } 24 \mathrm{kDa}\end{array}$ & $47 \% *$ & $96 \% *$ & $99 \% *$ & No & $N / E$ & {$[60]$} \\
\hline rT24-MAPIA & $\begin{array}{l}\text { Recombinant } \\
\text { from } 24 \mathrm{kDa}\end{array}$ & $60 \%$ & $97 \%$ & $99 \%$ & S. mansoni & $N / E$ & [83] \\
\hline rT24-MICT & $\begin{array}{l}\text { Recombinant } \\
\text { from } 24 \mathrm{kDa}\end{array}$ & $N / E$ & $94 \%$ & $99 \%$ & No & $N / E$ & {$[180]$} \\
\hline TsRS1-EITB & $\begin{array}{l}\text { Synthetic } \\
\text { from } 8 \mathrm{kDa}\end{array}$ & $85 \% *$ & $96 \% *$ & $98 \%$ & $N / E$ & $\mathrm{~N} / \mathrm{E}$ & [68] \\
\hline TsRS1-ELISA & $\begin{array}{l}\text { Synthetic } \\
\text { from } 8 \mathrm{kDa}\end{array}$ & $50 \% *$ & $77 \% *$ & $93 \%$ & $N / E$ & $N / E$ & {$[68]$} \\
\hline $\begin{array}{l}\text { TsRS1- } \\
\text { FASTELISA }\end{array}$ & $\begin{array}{l}\text { Synthetic } \\
\text { from } 8 \mathrm{kDa}\end{array}$ & $N / E$ & $100 \% *$ & $100 \%$ & $N / E$ & $N / E$ & {$[61]$} \\
\hline Ts18var1-EITB & $\begin{array}{l}\text { Synthetic } \\
\text { from } 8 \mathrm{kDa}\end{array}$ & $35 \% *$ & $97 \% *$ & $100 \%$ & $\mathrm{~N} / \mathrm{E}$ & $\mathrm{N} / \mathrm{E}$ & {$[68]$} \\
\hline Ts18var1-ELISA & $\begin{array}{l}\text { Synthetic } \\
\text { from } 8 \mathrm{kDa}\end{array}$ & $44 \% *$ & $95 \% *$ & $85 \%$ & $\mathrm{~N} / \mathrm{E}$ & $\mathrm{N} / \mathrm{E}$ & [68] \\
\hline Ts18var1-ELISA & $\begin{array}{l}\text { Synthetic } \\
\text { from } 8 \mathrm{kDa}\end{array}$ & $\mathrm{N} / \mathrm{E}$ & $90 \% *$ & $90 \% *$ & No & Yes & {$[59]$} \\
\hline $\begin{array}{l}\text { Ts18var1- } \\
\text { FASTELISA }\end{array}$ & $\begin{array}{l}\text { Synthetic } \\
\text { from } 8 \mathrm{kDa}\end{array}$ & $N / E$ & $97 \% *$ & $100 \%$ & $N / E$ & $N / E$ & {$[61]$} \\
\hline $\begin{array}{l}\text { Ts18var1- } \\
\text { QuickELISA }\end{array}$ & $\begin{array}{l}\text { Synthetic } \\
\text { from } 8 \mathrm{kDa}\end{array}$ & $16 \% *$ & $90 \% *$ & $96 \% *$ & No & $\mathrm{N} / \mathrm{E}$ & {$[60]$} \\
\hline Ts8B2-ELISA & $\begin{array}{l}\text { Recombinant } \\
\text { from } 8 \mathrm{kDa}\end{array}$ & $N / E$ & $97 \%$ & $93 \%$ & $\begin{array}{l}\text { Echinoccocosis } \\
\text { Schistosomiasis }\end{array}$ & No & {$[72,73]$} \\
\hline 10 kDa-EITB & $\begin{array}{l}\text { Native } 10 \mathrm{kDa} \\
\text { from fluid cyst }\end{array}$ & $\mathrm{N} / \mathrm{E}$ & $85 \% *$ & $\mathrm{~N} / \mathrm{E}$ & Echinoccocosis & $\mathrm{N} / \mathrm{E}$ & {$[74]$} \\
\hline 10 kDa-EITB & $\begin{array}{l}\text { Recombinant } \\
\text { from } 10 \mathrm{kDa}\end{array}$ & $N / E$ & $97 \% *$ & $98 \%$ & Echinoccocosis & $N / E$ & {$[71]$} \\
\hline 53/25 kDa EITB & $\begin{array}{l}\text { Cathepsine L- } \\
\text { like 53/25 kDa }\end{array}$ & $78 \% *$ & $96 \% *$ & $98 \% *$ & Echinococcosis & $N / E$ & {$[77]$} \\
\hline 53/25 kDa ELISA & $\begin{array}{l}\text { Cathepsine L- } \\
\text { like 53/25 kDa }\end{array}$ & $84 \% *$ & $98 \% *$ & $93 \% *$ & $\begin{array}{l}\text { Echinococcosis } \\
\text { T. saginata }\end{array}$ & $\mathrm{N} / \mathrm{E}$ & {$[77]$} \\
\hline $\begin{array}{l}53 / 25 \mathrm{kDa} \\
\text { dotELISA }\end{array}$ & $\begin{array}{l}\text { Cathepsine L- } \\
\text { like 53/25 kDa }\end{array}$ & $29.4 \% *$ & $84.8 \% *$ & $100 \% *$ & Echinococcosis & $N / E$ & [78] \\
\hline
\end{tabular}

Notes: NCC, neurocysticercosis; LLGP-EITB, lentil lectin glycoprotein enzyme-linked immunoelectrotransfer blot; CSF, cerebrospinal fluid; ELISA, enzyme-linked immunosorbent assay; MAPIA, multiantigen print immunoassay; MICT, Magnetic ImmunoChromatographic Test; N/E, not evaluated.

*Calculated using sera with previously positive serology. 
works well in blood samples eluted from filter paper, ${ }^{120,121}$ with a high agreement with paired serum samples, ${ }^{122,123}$ although some antibody activity is lost along the process. Placing the piece of filter paper in a liquid buffer preserves the amount of recovered antibodies. $^{124}$

Detection of antibodies in other biological fluids has not been extensively explored. Two reports showed low sensitivity in urine. ${ }^{125,126}$ Saliva gave promising results ${ }^{45,127}$ for diagnosis or even for IgG4 monitoring, ${ }^{100}$ but no further experiments have been reported. Tears have also been used for diagnosis of ophthalmic cysticercosis (IgA response) with 100\% sensitivity and $92 \%$ specificity, although this was tested on only a few cases. ${ }^{128}$

\section{Antigen Detection Tests for Cysticercosis}

Direct immunodiagnosis (detection of products of the infective agent in the host) has the advantage of demonstrating active infection and in most cases, the antigen levels are associated with the infective burden and thus the severity of the infection, so this type of test can be used to determine therapeutic decisions and guide the prognosis of the patients. Cure is frequently associated with negative antigen results, and on the other hand, relapses, reinfections, or complications result in increases in circulating antigen levels. Unfortunately, in most cases, the sensitivity of antigen detection assays is inferior to that of indirect, antibody-detecting assays.

The initial reports on finding $T$. solium antigens in the CSF of patients with NCC used ELISA assays with rabbit polyclonal antisera raised against crude cysticercal extracts. Their results were promising, particularly in terms of specificity (likely resulting from the use of CSF instead of serum, as detailed above). ${ }^{129,130}$ As expected, circulating antigen cannot be demonstrated in the CSF of all NCC patients. Also, only a fraction of all antigens present in the cyst fluid can be detected in the patient's CSF. ${ }^{131,132}$ Circulating antigen can also be detected in serum, as initially demonstrated for $T$. saginata cysticercosis in cattle $^{133}$ and later in human samples. ${ }^{134}$

Monoclonal antibody (MoAb)-based antigen detection greatly improved the performance of these assays. The initial tests for T. solium antigen detection originated from assays developed against $T$. saginata and performed well thanks to an unexpected interspecies cross-reaction. In 1989, Harrison et al. developed a MoAb against a repetitive epitope from excretory/secretory glycoprotein products of the $T$. saginata metacestode, HP10. In an ELISA format, HP10 detected circulating antigen in cattle with 200 or more live cysts, with levels detectable in cattle serum as early as 4-5 weeks post-infection. No crossreactions other than the above described with $T$. solium were reported. ${ }^{133}$ The sensitivity of the HP10 ELISA in CSF of confirmed NCC cases was $72 \%{ }^{36} \mathrm{~A}$ similar method was pursued by Brandt et al. in 1992. They found eight MoAbs of IgM isotype, which when used in combination, had a lower detection limit of 88 live cysts in infected cattle, and also were able to detect antigens as late as 5 weeks post-infection. ${ }^{134}$ These MoAbs were also directed against repetitive glycoprotein epitopes. ${ }^{135}$ Further studies generated IgG MoAbs, which improved the antigen assay performance, reaching 92\% sensitivity and $98.7 \%$ specificity in sera from cysticercosisinfected cattle. They also showed that the target antigen was thermostable. Heat treatment of samples prior to testing gave better results, in particular fewer non-specific reactions (Fig. 2). ${ }^{136}$

MoAbs against $T$. solium were first described in 1991. ${ }^{137}$ The initial report concludes that the antigen detection test performed well for diagnosis of $T$. solium cysticercosis, but was not $100 \%$ sensitive; the test worked better on CSF than on serum, and antigen levels dropped to undetectable levels after successful treatment. ${ }^{137}$ Another anti-T. solium $\mathrm{MoAb}$ targeted cyst fluid (1F11, IgG1 isotype) and had a diagnostic sensitivity of $82 \%$, mainly missing cases with fewer lesions or only calcifications. ${ }^{138}$ This same group also developed MoAb 4F8. A 4F8-based ELISA was used by them to demonstrate that patients with subcutaneous nodules had higher levels of circulating antigen, likely because subcutaneous cysticercosis is found in patients with higher parasite burdens. $^{139}$

Interesting and very promising tools are nanobodies (Nbs), single domain antibodies that are produced in immunized camelids. These molecules are, highly stable and soluble, devoid of light chains, and capable of binding to antigens with high affinity and specificity. Their small size (12-15 kDa) allows detection of hidden epitopes and expression in various microorganisms. ${ }^{140} \mathrm{Nbs}$ directed against an $8 \mathrm{kDa}$ antigen of the metacestode have been developed and proven specific for $T$. solium, without cross-reactions with $T$. hydatigena, $T$. saginata, T. crassiceps, and Trichinella spiralis (Table 2). ${ }^{141}$ Further work is needed to determine the utility of these reagents for antigen detection in $T$. solium cysticercosis.

\section{Advantages and disadvantages of antigen detection in cysticercosis}

Currently available antigen capture assays do not reach the same sensitivity and specificity as antibodydetecting assays, so they are not the best option for initial diagnosis of clinical cases. They, however, provide an exceptional tool for clinical management and follow-up of confirmed cases. As described above, the levels of circulating antigen correlate with 


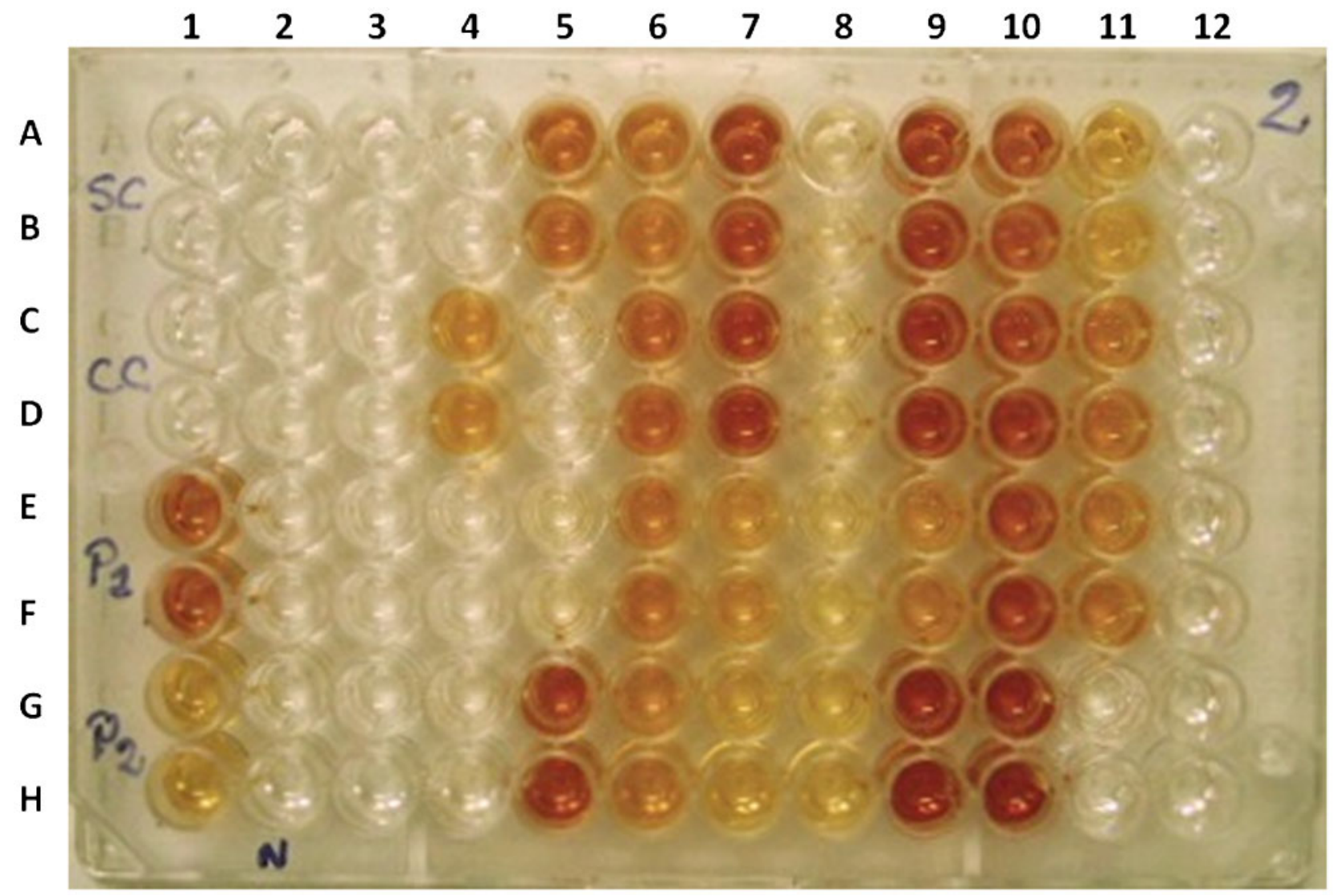

Figure 2 Antigen detection enzyme-linked immunosorbent assay (ELISA) using MoAbs B158 and B60 showing serial samples of different cases.

the severity and type of NCC infection. In intraparenchymal brain cysticercosis, the higher the number of viable cysts, the higher the antigen level, both in humans ${ }^{142,143}$ and in pigs. ${ }^{144}$ In cases of extraparenchymal NCC, which carry a poorer prognosis, the levels of antigen are much higher, particularly in patients with basal subarachnoid $\mathrm{NCC}^{10,145-147}$ and also correlate with the volume of the lesions except when hydrocephalus is present. (unpublished data, the Cysticercosis Working Group in Peru 2012) Very high antigen levels should thus raise the suspicion of extraparenchymal NCC or massive intraparenchymal NCC. Since the levels of antigen drop quickly in cured NCC patients, serum antigen monitoring is of great help in the follow-up of clinical cases. ${ }^{142,145-149}$ Detectable levels of circulating antigen do not always correlate with neurological symptoms. A study in India followed 42 antigen-positive individuals for up to 5 years, and none of them developed neurological symptoms associated with NCC. ${ }^{150}$ It follows that the isolated finding of circulating antigen without neurological symptoms or compatible neuroimage should not be interpreted as an indication for therapeutic intervention.

The usefulness of population-based antigen detection surveys is yet unclear. From the available data, the expected proportion of asymptomatic individuals with viable brain cysticerci and thus positive antigen levels should be quite small. Its use would likely be more productive if focused in patients with compatible symptoms such as seizures or intracranial hypertension. ${ }^{151,152}$ In field studies, one would expect

Table 2 Antibodies used to diagnose NCC by antigen capture.

\begin{tabular}{|c|c|c|c|c|c|c|c|}
\hline Test & Type of antibody & $\begin{array}{l}\text { Sensitivity } \\
\text { (1 lesion) }\end{array}$ & $\begin{array}{l}\text { Sensitivity } \\
\text { (>2 lesions) }\end{array}$ & Specificity & $\begin{array}{l}\text { Cross- } \\
\text { reactions }\end{array}$ & $\begin{array}{l}\text { CSF better } \\
\text { than serum }\end{array}$ & References \\
\hline HP10-ELISA & $\begin{array}{l}\text { MoAbs against } T \\
\text { saginata larval } \\
\text { antigens from fluid } \\
\text { and tegument of cyst }\end{array}$ & $N / E$ & $75 \% * *$ & $100 \% * *$ & $\begin{array}{l}\text { T. solium } \\
\text { T. hydatigena }\end{array}$ & No & {$[36,133]$} \\
\hline $\begin{array}{l}\text { B158/B60- } \\
\text { ELISA }\end{array}$ & $\begin{array}{l}\text { MoAbs against } T \text {. } \\
\text { saginata excretory/secretory } \\
\text { larval antigens }\end{array}$ & $N / E$ & $N / E$ & $N / E$ & $\begin{array}{l}\text { T. solium } \\
T . \text { hydatigena }\end{array}$ & Yes & {$[10,134,136,181]$} \\
\hline
\end{tabular}

Notes: NCC, neurocysticercosis; CSF, cerebrospinal fluid; ELISA, enzyme-linked immunosorbent assay; N/E, not evaluated. **Calculated using only CSF. 
to find a higher prevalence of antibody-positive individuals than antigen-positive individuals, since antibody responses occur in non-viable infections and individuals with exposure only, and for an unknown time after resolution. However, population-based studies show discordant results. In a community in Mexico, $1 \%$ of all people were positive to circulating antigen versus $4.8 \%$ seropositive to antibodies. ${ }^{151} \mathrm{In}$ Ecuador, $2.25 \%$ of 800 participants in a rural community were positive for antigen, while the antibody seroprevalence measured in a subset of 100 randomly selected samples was $40 \% .{ }^{153}$ On the other hand, a study in South Africa found more antigen-positive than antibody-positive cases, ${ }^{154}$ and another study in Burundi found higher prevalence of antibodies in patients with epilepsy than in controls but no differences in the frequencies of antigenpositive cases between these groups. ${ }^{155}$

\section{Appropriate samples for antigen detection}

Compared to serum, CSF had better sensitivity (78\% versus $68 \%$ ) and specificity ( $73 \%$ versus $60 \%$ ) for antigen detection, when MoAbs are used as capture antibodies. ${ }^{10,137}$ Assays using polyclonal rabbit antisera against specific purified antigens did not show differences in serum versus CSF. ${ }^{156}$ Also no advantage was demonstrated when using saliva. ${ }^{157}$

Urine samples are easy to collect, non-invasive and thus are easily provided by patients or villagers. Immunodiagnostic tests in urine have been developed for a variety of infectious diseases, ${ }^{158-161}$ including cysticercosis. The initial study found detectable antigen levels in five out of eight confirmed NCC cases, in an agglutination assay using rabbit antisera to a $T$. solium total metacestode extract. ${ }^{162}$ We have found $92 \%$ sensitivity in patients with two or more viable cysts, and $62.5 \%$ in single lesion cases using the MoAbs described by Van Kerckhoven et al., ${ }^{136}$ as well as a strong correlation between serum and urine levels of antigen. ${ }^{163}$ Mwape et al. ${ }^{164}$ tested paired urine and serum samples collected in Zambia and Ecuador. A very high agreement $(90 \%)$ was found between samples of the same individual, but lower specificity when urine samples were tested. The Zambian samples had more non-specific reactions. Urine can also be concentrated to take advantage of the large sample volumes, which can be obtained. Lyophilization avoids the need for further refrigeration or freezing and also results in a slight increase in sensitivity. It, however, also decreases specificity by $2-4 \%$. Other concentration methods were less efficient. ${ }^{163}$

\section{Single-Lesional NCC}

A single brain-enhancing lesion is a very frequent presentation of NCC in the Indian subcontinent, where it is also a major contributor to seizures in younger patients. ${ }^{165-167}$ In Latin America, the proportion of NCC patients with a single-enhancing lesion varies from 3.5 to $34 \%,{ }^{168}$ likely reflecting different definitions of a single-enhancing lesion. More importantly, other infections, tumors, vascular lesions, and other etiologies need to be considered in the differential diagnosis of single brain lesions, ${ }^{168-170}$ and thus serology could be of great help in saving unnecessary invasive procedures or treatments. ${ }^{171}$

In general, all immunodiagnostic tests show low sensitivity for the diagnosis of single-lesional NCC, even worse when the lesion has entered in an involutive, degenerative process of resolution following antiparasitic treatment or by natural evolution ('single-enhancing lesion' or single cysticercal granuloma'). A proportion of these cases could also correspond to early lesions, caused by cysticerci, that resolved soon after infection, before full establishment and thus not provoking a strong immune response. ${ }^{172}$ Most seronegative NCC cases in ELISA $^{111}$ or in the LLGP-EITB ${ }^{48,50,51}$ correspond to cases with a single lesion, although the estimates of sensitivity of the assays in this type of NCC vary greatly. Prabhakaran et al. reported an increase in sensitivity following the use of urea to expose the tertiary structure of the antigenic glycoproteins, detecting $46 \%$ of previously negative cases in EITB. ${ }^{173}$

\section{DNA-Based Technology}

The greatest contribution of DNA-based technology has been in the genotyping of the genus Taenia, which has served to determine the phylogeny and taxonomy of its species and to understand the level of genetic diversity in the genus. ${ }^{174}$ Another important contribution of molecular biology is the identification and production of antigenic molecules used as vaccines candidates or as candidates for serological tests.

Direct use of molecular techniques for NCC diagnosis was first reported in 2006 and demonstrated T. solium DNA in the CSF of 29 of 30 consecutive patients, using a PCR with primers against pTsol9, specific for T. solium. ${ }^{175}$ Another study, using primers against HDP2, based on a noncoding sequence of $T$. saginata, which cross-reacts with T. solium, also found parasite DNA in human $\mathrm{CSF}$, as well as reported higher sensitivity by type of NCC (10/14 extraparenchymal NCC cases compared to $4 / 24$ of intraparenchymal, degenerating NCC). ${ }^{176}$ A recent study compared antigen and antibody capture techniques with a pTsol9 PCR. In 150 CSFs of patients with different types of NCC, PCR had the best sensitivity, although its specificity was only $80 \%$ using negative controls from Mexico. Unexpectedly, 28/31 patients with only calcified 


\begin{tabular}{ll}
\hline Test & \multicolumn{1}{c}{ Challenges } \\
\hline Antibody test & Identify antigens or epitopes to maintain high sensitivity and \\
specificity compared to native antigens. & Increase the sensitivity for single brain lesion. \\
& Identify antigens capable to differentiate exposure from infection. \\
& Identify antigens capable to differentiate viable and non-viable cysticercosis. \\
& Produce these antigens or epitopes in recombinant or synthetic way to \\
& have an easier and reproducible source of antigen. \\
& Use these antigens or epitopes to develop a point of care test, to have a \\
& primary tool in field settings. \\
& Produce MoAbs or nanobodies against T. solium metacestodes in order to \\
& increase sensitivity and specificity. \\
& Standardize a qualitative assay with a better reproducibility and repeatability. \\
& Produce a test capable of differentiating viable and non-viable cysticercosis, \\
& with a high PPV for extraparenchymal NCC. \\
& Assay needs to perform well in urine samples to avoid invasive and \\
& risky sampling methods. \\
& Develop a point of care test, to have a primary tool in field settings.
\end{tabular}

Note: NCC, neurocysticercosis.

NCC were PCR-positive (compared to 19 antibodypositive and seven antigen-positive by EITB and ELISA-HP10, respectively). ${ }^{177}$ Only one study using PCR in porcine cysticercosis has been published, with poor performance: sensitivities of $23 \%$ and $32 \%$ in heavily infected animals, which improved to $64 \%$ using a nested PCR. On the other hand, these PCR assays were $100 \%$ specific. $^{178}$

\section{Conclusion}

A variety of laboratory methods are available to support the diagnosis of NCC. The LLGP-EITB remains the optimal assay for clinical diagnosis, while antigen detection is useful to monitor patients after anthelminthic treatment (Table 3). Despite initial reports, molecular methods have not yet proven useful to diagnose NCC in clinical settings. More research is necessary to evaluate their real potential.

\section{References}

1 Moses A. Dos metodos biolojicos de diagnostico nas cisticercozes. Mem Inst Oswaldo Cruz. 1911;3:322-6.

2 Waterhouse R. Cysticercus cellulosae in the central nervous system: with an account of two cases. Q J Med. 1913:6:469-85.

3 Weinberg M. Recherche des anticorps specifiques dans la distomatose et la cysticercose. C R Soc Biol Paris. 1909;66:219-21.

4 Takayanagui OM, Jardim E. [Clinical aspects of neurocysticercosis: analysis of 500 cases]. Arq Neuro-psiquiatr. 1983;41:50-63.

5 Salinas P, Sandoval L, Rugiero E, Contreras MC. [Diagnosis of human neurocysticercosis by ELISA-IgG using a purified antigen]. Bol Chil Parasitol. 1996;51:85-90.

6 Bueno EC, Snege M, Vaz AJ, Leser PG. Serodiagnosis of human cysticercosis by using antigens from vesicular fluid of Taenia crassiceps cysticerci. Clin Diagn Lab Immunol. 2001;8:1140-4.

7 Teive HA, de Almeida SM, Werneck LC. The Brazilian contribution to the study of neurocysticercosis: Moses and Lange's role in cerebrospinal fluid diagnosis. Arq Neuropsiquiatr. 2006;64:534-7

8 Garcia HH, Gilman RH, Catacora M, Verastegui M, Gonzalez AE, Tsang VC. Serologic evolution of neurocysticercosis patients after antiparasitic therapy. Cysticercosis Working Group in Peru. J Infect Dis. 1997;175:486-9.

9 Ito A, Craig PS. Immunodiagnostic and molecular approaches for the detection of taeniid cestode infections. Trends Parasitol. 2003;19:377-81.
10 Rodriguez S, Dorny $\mathrm{P}$, Tsang VC, Pretell EJ, Brandt J, Lescano AG, et al. Detection of Taenia solium antigens and anti-T. solium antibodies in paired serum and cerebrospinal fluid samples from patients with intraparenchymal or extraparenchymal neurocysticercosis. J Infect Dis. 2009;199:134552.

11 Biagi F, Navarrete F, Pina A, Santiago AM, Tapia L. [Study of 3 serological reactions in the diagnosis of cysticercosis]. Rev Med Hosp Gen (Mex). 1961;24:501-8.

12 Biagi F, Tay J. A precipitation reaction for the diagnosis of cysticercosis. Am J Trop Med Hyg. 1958;7:63-5.

13 Flisser A, Tarrab R, Willms K, Larralde C. [Immunoelectrophoresis and double immunodiffusion in the diagnosis of human cerebral cysticercosis]. Arch Invest Med. 1975;6:1-12.

14 Flisser A, Bulnes I, Diaz ML, Luna R, Woodhouse E, Beltran $\mathrm{F}$, et al. [Seroepidemiologic study of human cysticerosis in the predominantly indigenous rural Indian population of the State of Chiapas]. Arch Invest Med. 1976;7:107-13.

15 Schoop G, Lamina J. [Immunological evidence of cysticercosis in the living animal. I. Allergic intracutaneous test]. Deutsch Tierarztl Wochenschr. 1970;77:156-61.

16 Schenone H, Aranda R, Concha L, Knierim F, Rojas A, Cofre $\mathrm{H}$. [Survey on undiagnosed hydatidosis and cysticercosis by means of immunobiological reactions]. Bol Chil Parasitol. 1971;26:121-3

17 Rydzewski AK, Chisholm ES, Kagan IG. Comparison of serologic tests for human cysticercosis by indirect hemagglutination, indirect immunofluorescent antibody, and agar gel precipitin tests. J Parasitol. 1975;61:154-5.

18 Flisser A, Perez-Montfort R, Larralde C. The immunology of human and animal cysticercosis: a review. Bull World Health Organ. 1979;57:839-56.

19 Engvall E, Perlmann P. Enzyme-linked immunosorbent assay (ELISA). Quantitative assay of immunoglobulin G. Immunochemistry. 1971;8:871-4.

20 Arambulo PV, 3rd, Walls KW, Bullock S, Kagan IG. Serodiagnosis of human cysticercosis by microplate enzymelinked immunospecific assay (ELISA). Acta Trop. 1978;35:637.

21 Coker-Vann MR, Subianto DB, Brown P, Diwan AR, Desowitz R, Garruto RM, et al. ELISA antibodies to cysticerci of Taenia solium in human populations in New Guinea, Oceania, and Southeast Asia. Southeast Asian J Trop Med Public Health. 1981;12:499-505.

22 Diwan AR, Coker-Vann M, Brown P, Subianto DB, Yolken R, Desowitz R, et al. Enzyme-linked immunosorbent assay (ELISA) for the detection of antibody to cysticerci of Taenia solium. Am J Trop Med Hyg. 1982;31:364-9.

23 Costa JM, Ferreira AW, Makino MM, Camargo ME. Spinal fluid immunoenzymatic assay (ELISA) for neurocysticercosis. Rev Inst Med Trop Sao Paulo. 1982;24:337-41.

24 Mohammad IN, Heiner DC, Miller BL, Goldberg MA, Kagan IG. Enzyme-linked immunosorbent assay for the diagnosis of cerebral cysticercosis. J Clin Microbiol. 1984;20:775-9. 
25 Costa JM. [Immunoenzymatic test (ELISA) in the diagnosis of neurocysticercosis: study of various antigenic extracts in the detection of $\operatorname{IgG}$ antibodies in serum and cerebrospinal fluid samples]. Arq Neuro-psiquiatr. 1986;44:15-31.

26 Schantz PM, Shanks D, Wilson M. Serologic cross-reactions with sera from patients with echinococcosis and cysticercosis. Am J Trop Med Hyg. 1980;29:609-12.

27 Coker-Vann M, Brown P, Gajdusek DC. Serodiagnosis of human cysticercosis using a chromatofocused antigenic preparation of Taenia solium cysticerci in an enzyme-linked immunosorbent assay (ELISA). Trans R Soc Trop Med Hyg. 1984;78:492-6.

28 Gottstein B, Tsang VC, Schantz PM. Demonstration of species-specific and cross-reactive components of Taenia solium metacestode antigens. Am J Trop Med Hyg. 1986;35:308-13.

29 Mendoza J, Molina JM, Rojas A, Leiva J, Sanchez JC, de la Rosa M. [Evaluation of 2 serological techniques in the diagnosis of neurocysticercosis: complement fixation reaction and Western blot]. Enferm Infecc Microbiol Clin. 1991;9:53742.

30 Chavarria A, Fleury A, Garcia E, Marquez C, Fragoso G, Sciutto E. Relationship between the clinical heterogeneity of neurocysticercosis and the immune-inflammatory profiles. Clin Immunol. 2005;116:271-8.

31 Flisser A, Woodhouse E, Larralde C. Human cysticercosis: antigens, antibodies and non-responders. Clin Exp Immunol. 1980;39:27-37.

32 Plancarte A, Flisser A, Larralde C. Fibronectin-like properties in antigen B from the cysticercus of Taenia solium. Cytobios. 1983;36:83-93.

33 Laclette JP, Merchant MT, Willms K. Histological and ultrastructural localization of antigen $\mathrm{B}$ in the metacestode of Taenia solium. J Parasitol. 1987;73:121-9.

34 Laclette JP, Landa A, Arcos L, Willms K, Davis AE, Shoemaker CB. Paramyosin is the Schistosoma mansoni (Trematoda) homologue of antigen B from Taenia solium (Cestoda). Mol Biochem Parasitol. 1991;44:287-95.

35 Espinoza B, Ruiz-Palacios G, Tovar A, Sandoval MA, Plancarte A, Flisser A. Characterization by enzyme-linked immunosorbent assay of the humoral immune response in patients with neurocysticercosis and its application in immunodiagnosis. J Clin Microbiol. 1986;24:536-41.

36 Correa D, Sandoval MA, Harrison LJ, Parkhouse RM, Plancarte A, Meza-Lucas A, et al. Human neurocysticercosis: comparison of enzyme immunoassay capture techniques based on monoclonal and polyclonal antibodies for the detection of parasite products in cerebrospinal fluid. Trans R Soc Trop Med Hyg. 1989;83:814-6.

37 Das S, Mahajan RC, Ganguly NK, Sawhney IM, Dhawan V, Malla N. Detection of antigen B of Cysticercus cellulosae in cerebrospinal fluid for the diagnosis of human neurocysticercosis. Trop Med Int Health. 2002;7:53-8.

38 Grogl M, Estrada JJ, MacDonald G, Kuhn RE. Antigenantibody analyses in neurocysticercosis. J Parasitol. 1985;71:433-42.

39 Tsang VC, Peralta JM, Simons AR. Enzyme-linked immunoelectrotransfer blot techniques (EITB) for studying the specificities of antigens and antibodies separated by gel electrophoresis. Methods Enzymol. 1983;92:377-91.

40 Kim SI, Kang SY, Cho SY, Hwang ES, Cha CY. Purification of cystic fluid antigen of Taenia solium metacestodes by affinity chromatography using monoclonal antibody and its antigenic characterization. Kisaengch'unghak Chapchi. 1986;24:145-8.

41 Kumar D, Gaur SN. Serodiagnosis of porcine cysticercosis by enzyme-linked immunosorbent assay (ELISA) using fractionated antigens. Vet Parasitol. 1987;24:195-202.

42 Rossi CL. [Evaluation of antigenic fractions of Cysticercus cellulosae for the immunodiagnosis of neurocysticercosis using antibody-lectin conjugates]. Arq Neuro-psiquiatr. 1989;47: 287-90.

43 da Silva AD, Quagliato EM, Rossi CL. A quantitative enzyme-linked immunosorbent assay (ELISA) for the immunodiagnosis of neurocysticercosis using a purified fraction from Taenia solium cysticerci. Diagn Microbiol Infect Dis. 2000;37:87-92.

44 Tsang VC, Brand JA, Boyer AE. An enzyme-linked immunoelectrotransfer blot assay and glycoprotein antigens for diagnosing human cysticercosis (Taenia solium). J Infect Dis. 1989;159:50-9.
45 Feldman M, Plancarte A, Sandoval M, Wilson M, Flisser A. Comparison of two assays (EIA and EITB) and two samples (saliva and serum) for the diagnosis of neurocysticercosis. Trans R Soc Trop Med Hyg. 1990;84:559-62.

46 Diaz JF, Verastegui M, Gilman RH, Tsang VC, Pilcher JB, Gallo $\mathrm{C}$, et al. Immunodiagnosis of human cysticercosis (Taenia solium): a field comparison of an antibody-enzymelinked immunosorbent assay (ELISA), an antigen-ELISA, and an enzyme-linked immunoelectrotransfer blot (EITB) assay in Peru. The Cysticercosis Working Group in Peru (CWG). Am J Trop Med Hyg. 1992;46:610-5.

47 Schantz PM, Sarti E, Plancarte A, Wilson M, Criales JL, Roberts J, et al. Community-based epidemiological investigations of cysticercosis due to Taenia solium: comparison of serological screening tests and clinical findings in two populations in Mexico. Clin Infect Dis. 1994;18:879-85.

48 Proano-Narvaez JV, Meza-Lucas A, Mata-Ruiz O, GarciaJeronimo RC, Correa D. Laboratory diagnosis of human neurocysticercosis: double-blind comparison of enzyme-linked immunosorbent assay and electroimmunotransfer blot assay. $\mathbf{J}$ Clin Microbiol. 2002;40:2115-8.

49 Gonzalez AE, Cama V, Gilman RH, Tsang VC, Pilcher JB, Chavera A, et al. Prevalence and comparison of serologic assays, necropsy, and tongue examination for the diagnosis of porcine cysticercosis in Peru. Am J Trop Med Hyg. 1990;43:194-9.

50 Wilson M, Bryan RT, Fried JA, Ware DA, Schantz PM, Pilcher JB, et al. Clinical evaluation of the cysticercosis enzyme-linked immunoelectrotransfer blot in patients with neurocysticercosis. J Infect Dis. 1991;164:1007-9.

51 Singh G, Kaushal V, Ram S, Kaushal RK, Dhanuka AK, Khurana S. Cysticercus immunoblot assay in patients with single, small enhancing lesions and multilesional neurocysticercosis. J Assoc Phys India. 1999;47:476-9.

52 Greene RM, Wilkins PP, Tsang VC. Diagnostic glycoproteins of Taenia solium cysts share homologous $14-$ and $18-\mathrm{kDa}$ subunits. Mol Biochem Parasitol. 1999;99:257-61.

53 Hancock K, Pattabhi S, Greene RM, Yushak ML, Williams F, Khan A, et al. Characterization and cloning of GP50, a Taenia solium antigen diagnostic for cysticercosis. Mol Biochem Parasitol. 2004;133:115-24.

54 Hancock K, Pattabhi S, Whitfield FW, Yushak ML, Lane WS, Garcia HH, et al. Characterization and cloning of T24, a Taenia solium antigen diagnostic for cysticercosis. Mol Biochem Parasitol. 2006;147:109-17.

55 Kojic EM, White AC Jr. A positive enzyme-linked immunoelectrotransfer blot assay result for a patient without evidence of cysticercosis. Clin Infect Dis. 2003;36:e7-9.

56 Furrows SJ, McCroddan J, Bligh WJ, Chiodini P. Lack of specificity of a single positive $50-\mathrm{kDa}$ band in the electroimmunotransfer blot (EITB) assay for cysticercosis. Clin Microbiol Infect. 2006;12:459-62.

57 Tsang VC, Pilcher JA, Zhou W, Boyer AE, Kamango-Sollo EI, Rhoads ML, et al. Efficacy of the immunoblot assay for cysticercosis in pigs and modulated expression of distinct IgM/ IgG activities to Taenia solium antigens in experimental infections. Vet Immunol Immunopathol. 1991;29:69-78.

58 Plancarte A, Hirota C, Martinez-Ocana J, MendozaHernandez G, Zenteno E, Flisser A. Characterization of GP39-42 and GP24 antigens from Taenia solium cysticerci and of their antigenic GP10 subunit. Parasitol Res. 1999;85:680-4.

59 Bueno EC, Scheel CM, Vaz AJ, Machado LR, Livramento JA, Takayanagui OM, et al. Application of synthetic 8-kD and recombinant GP50 antigens in the diagnosis of neurocysticercosis by enzyme-linked immunosorbent assay. Am J Trop Med Hyg. 2005;72:278-83.

60 Lee YM, Handali S, Hancock K, Pattabhi S, Kovalenko VA, Levin A, et al. Serologic diagnosis of human Taenia solium cysticercosis by using recombinant and synthetic antigens in QuickELISA. Am J Trop Med Hyg. 2011;84:587-93.

61 Hancock K, Khan A, Williams FB, Yushak ML, Pattabhi S, Noh J, et al. Characterization of the 8-kilodalton antigens of Taenia solium metacestodes and evaluation of their use in an enzyme-linked immunosorbent assay for serodiagnosis. J Clin Microbiol. 2003;41:2577-86.

62 Maddison SE, Slemenda SB, Schantz PM, Fried JA, Wilson M, Tsang VC. A specific diagnostic antigen of Echinococcus granulosus with an apparent molecular weight of $8 \mathrm{kDA}$. Am J Trop Med Hyg. 1989;40:377-83.

63 Poretti D, Felleisen E, Grimm F, Pfister M, Teuscher F, Zuercher $\mathrm{C}$, et al. Differential immunodiagnosis between 
cystic hydatid disease and other cross-reactive pathologies Am J Trop Med Hyg. 1999;60:193-8.

64 Monteiro KM, Scapin SM, Navarro MV, Zanchin NI, Cardoso MB, da Silveira NP, et al. Self-assembly and structural characterization of Echinococcus granulosus antigen B recombinant subunit oligomers. Biochim Biophys Acta. 2007; 1774:278-85.

65 Jia WZ, Yan HB, Lou ZZ, Ni XW, Liu HX, Li HM, et al. Genetic variation of the $8-\mathrm{kDa}$ glycoprotein family from Echinococcus granulosus, Taenia multiceps and Taenia hydatigena. Chin Med J. 2011;124:2849-56.

66 Rigano R, Profumo E, Bruschi F, Carulli G, Azzara A, Ioppolo $\mathrm{S}$, et al. Modulation of human immune response by Echinococcus granulosus antigen B and its possible role in evading host defenses. Infect Immun. 2001;69:288-96.

67 Greene RM, Hancock K, Wilkins PP, Tsang VC. Taenia solium: molecular cloning and serologic evaluation of 14- and 18-kDa related, diagnostic antigens. J Parasitol. 2000;86:1001-

68 Scheel CM, Khan A, Hancock K, Garcia HH, Gonzalez AE, Gilman RH, et al. Serodiagnosis of neurocysticercosis using synthetic 8-kD proteins: comparison of assay formats. Am J Trop Med Hyg. 2005;73:771-6.

69 Ferrer E, Sanchez J, Milano A, Alvarez S, La Rosa R, Lares $\mathrm{M}$, et al. Diagnostic epitope variability within Taenia solium $8 \mathrm{kDa}$ antigen family: implications for cysticercosis immunodetection. Exp Parasitol. 2012;130:78-85.

70 Simac C, Michel P, Andriantsimahavandy A, Esterre P, Michault A. [Value of immunodiagnosis by ELISA and Western blotting for the diagnostic and therapeutic management of neurocysticercosis]. Arch Inst Pasteur Madagascar. 1994;61:21-7.

71 Chung JY, Bahk YY, Huh S, Kang SY, Kong Y, Cho SY. A recombinant $10-\mathrm{kDa}$ protein of Taenia solium metacestodes specific to active neurocysticercosis. $\mathbf{J}$ Infect Dise. 1999; 180:1307-15.

72 Ferrer E, Bonay P, Foster-Cuevas M, Gonzalez LM, Davila I, Cortez MM, et al. Molecular cloning and characterisation of Ts8B1, Ts8B2 and Ts8B3, three new members of the Taenia solium metacestode $8 \mathrm{kDa}$ diagnostic antigen family. Mol Biochem Parasitol. 2007;152:90-100.

73 Ferrer E, Martinez-Escribano JA, Barderas ME, Gonzalez LM, Cortez MM, Davila I, et al. Peptide epitopes of the Taenia solium antigen Ts8B2 are immunodominant in human and porcine cysticercosis. Mol Biochem Parasitol. 2009;168:168-71.

74 Yang HJ, Chung JY, Yun D, Kong Y, Ito A, Ma L, et al. Immunoblot analysis of a $10 \mathrm{kDa}$ antigen in cyst fluid of Taenia solium metacestodes. Parasite Immunol. 1998;20:4838.

75 Baig S, Damian RT, Molinari JL, Tato P, Morales-Montor J, Welch $\mathrm{M}$, et al. Purification and characterization of a metacestode cysteine proteinase from Taenia solium involved in the breakdown of human IgG. Parasitology. 2005;131(Pt 3):411-6.

76 Li AH, Moon SU, Park YK, Na BK, Hwang MG, Oh CM, et al. Identification and characterization of a cathepsin L-like cysteine protease from Taenia solium metacestode. Vet Parasitol. 2006;141:251-9.

77 Zimic M, Pajuelo M, Rueda D, Lopez C, Arana Y, Castillo Y, et al. Utility of a protein fraction with cathepsin L-like activity purified from cysticercus fluid of Taenia solium in the diagnosis of human cysticercosis. Am J Trop Med Hyg. 2009;80:964-70.

78 Pina R, Gutierrez AH, Gilman RH, Rueda D, Sifuentes C, Flores $\mathrm{M}$, et al. A dot-ELISA using a partially purified cathepsin-L-like protein fraction from Taenia solium cysticerci, for the diagnosis of human neurocysticercosis. Ann Trop Med Parasitol. 2011;105:311-8.

79 Hernandez M, Beltran C, Garcia E, Fragoso G, Gevorkian G, Fleury A, et al. Cysticercosis: towards the design of a diagnostic kit based on synthetic peptides. Immunol Lett. 2000;71:13-7.

80 Fleury A, Beltran C, Ferrer E, Garate T, Harrison LJ, Parkhouse RM, et al. Application of synthetic peptides to the diagnosis of neurocysticercosis. Trop Med Int Health. 2003;8:1124-30.

81 Ferrer E, Cortez MM, Cabrera Z, Rojas G, Davila I, Alarcon de Noya B, et al. Oncospheral peptide-based ELISAs as potential seroepidemiological tools for Taenia solium cysticercosis/ neurocysticercosis in Venezuela. Trans R Soc Trop Med Hyg. 2005;99:568-76.

82 Noya O, Patarroyo ME, Guzman F, Alarcon de Noya B. Immunodiagnosis of parasitic diseases with synthetic peptides. Curr Protein Peptide Sci. 2003;4:299-308

83 Handali S, Klarman M, Gaspard AN, Noh J, Lee YM, Rodriguez $\mathrm{S}$, et al. Multiantigen print immunoassay for comparison of diagnostic antigens for Taenia solium cysticercosis and taeniasis. Clin Vaccine Immunol. 2010;17:68-72.

84 Handali S, Pattabhi S, Lee YM, Silva-Ibanez M, Kovalenko VA, Levin AE, et al. Development and evaluation of porcine cysticercosis QuickELISA in Triturus EIA analyzer. J Immunoassay Immunochem. 2010;31:60-70.

85 Salazar-Anton F, Lindh J. Taenia solium: a two-dimensional Western blotting method combined with the use of an ESTlibrary for the identification of immunogenic proteins recognized by sera from neurocysticercosis patients. Exp Parasitol. 2011;128:371-6.

86 Prasad A, Prasad KN, Yadav A, Gupta RK, Pradhan S, Jha $\mathrm{S}$, et al. Lymphocyte transformation test: a new method for diagnosis of neurocysticercosis. Diagn Microbiol Infect Dis. 2008;61:198-202.

87 Amit P, Prasad KN, Kumar GR, Shweta T, Sanjeev J, Kumar $\mathrm{PV}$, et al. Immune response to different fractions of Taenia solium cyst fluid antigens in patients with neurocysticercosis. Exp Parasitol. 2011;127:687-92.

88 Manoutcharian K, Sotelo J, Garcia E, Cano A, Gevorkian G. Characterization of cerebrospinal fluid antibody specificities in neurocysticercosis using phage display peptide library. Clin Immunol. 1999;91:117-21.

89 Hell RC, Amim P, de Andrade HM, de Avila RA, Felicori L, Oliveira AG, et al. Immunodiagnosis of human neurocysticercosis using a synthetic peptide selected by phage-display. Clin Immunol. 2009;131:129-38

90 da Silva Ribeiro V, Manhani MN, Cardoso R, Vieira CU, Goulart LR, Costa-Cruz JM. Selection of high affinity peptide ligands for detection of circulating antibodies in neurocysticercosis. Immunol Lett. 2010;129:94-9.

91 Manhani MN, Ribeiro VS, Cardoso R, Ueira-Vieira C, Goulart LR, Costa-Cruz JM. Specific phage-displayed peptides discriminate different forms of neurocysticercosis by antibody detection in the serum samples. Parasite Immunol. 2011;33:322-9.

92 Esquivel-Velazquez M, Ostoa-Saloma P, Morales-Montor J, Hernandez-Bello R, Larralde C. Immunodiagnosis of neurocysticercosis: ways to focus on the challenge. J Biomed Biotechnol. 2011;2011:516042.

93 Handali S, Gonzalez AE, Hancock K, Garcia HH, Roberts JM, Gilman RH, et al. Porcine antibody responses to Taenia solium antigens rGp50 and sTs18var1. Am J Trop Med Hyg. 2004; 71:322-6.

94 Corona T, Pascoe D, Gonzalez-Barranco D, Abad P, Landa L, Estanol B. Anticysticercous antibodies in serum and cerebrospinal fluid in patients with cerebral cysticercosis. J Neurol Neurosurg Psychiatry. 1986;49:1044-9.

95 Michault A, Leroy D, Coubes P, Laporte JP, Bertil G, Mignard C. [Immunologic diagnosis of the cerebrospinal fluid and serum in developing brain cysticercosis]. Pathol Biol (Paris). 1989;37:249-53.

96 Zini D, Farrell VJ, Wadee AA. The relationship of antibody levels to the clinical spectrum of human neurocysticercosis. J Neurol Neurosurg Psychiatry. 1990;53:656-61.

97 Short JA, Heiner DC, Hsiao RL, Andersen FL. Immunoglobulin E and G4 antibodies in cysticercosis. J Clin Microbiol. 1990;28:1635-9.

98 Intapan PM, Khotsri P, Kanpittaya J, Chotmongkol V, Maleewong W, Morakote N. Evaluation of IgG4 and total IgG antibodies against cysticerci and peptide antigens for the diagnosis of human neurocysticercosis by ELISA. Asian Pac J Allergy Immunol. 2008;26:237-44.

99 Huang B, Li G, Jia F, Liu F, Ge L, Li W, et al. Determination of specific IgG4 for diagnosis and therapeutic evaluation of cerebral cysticercosis. Chin Med J. 2002;115:580-3

100 Malla N, Kaur R, Ganguly NK, Sawhney IM, Mahajan RC. Utility of specific IgG4 response in saliva and serum samples for the diagnosis and follow up of human neurocysticercosis. Nepal Med Coll J. 2005;7:1-9.

101 Garcia HH, Gonzalez AE, Gilman RH, Palacios LG, Jimenez I, Rodriguez S, et al. Short report: transient antibody response in Taenia solium infection in field conditions-a major 
contributor to high seroprevalence. Am J Trop Med Hyg. 2001;65:31-2

102 Sarti-Gutierrez EJ, Schantz PM, Lara-Aguilera R, Gomez Dandoy H, Flisser A. Taenia solium taeniasis and cysticercosis in a Mexican village. Trop Med Parasitol. 1988;39:194-8.

103 Schantz PM, Sarti-Gutierrez E. Diagnostic methods and epidemiologic surveillance of Taenia solium infection. Acta Leiden. 1989;57:153-63.

104 Diaz Camacho SP, Candil Ruiz A, Suate Peraza V, Zazueta Ramos ML, Felix Medina M, Lozano R, et al. Epidemiologic study and control of Taenia solium infections with praziquantel in a rural village of Mexico. Am J Trop Med Hyg. 1991;45: 522-31.

105 Gonzalez AE, Gilman R, Garcia HH, McDonald J, Kacena K, Tsang VC, et al. Use of sentinel pigs to monitor environmental Taenia solium contamination. The Cysticercosis Working Group in Peru (CWG). Am J Trop Med Hyg. 1994;51: 847-50.

106 McManus DP. Improved diagnosis as an aid to better surveillance of Taenia solium cysticercosis, a potential public health threat to Papua New Guinea. Papua New Guinea Med J. 1995;38:287-94.

107 Rodriguez-Canul R, Allan JC, Dominguez JL, Villegas S, Cob $\mathrm{L}$, Rodriguez RI, et al. Application of an immunoassay to determine risk factors associated with porcine cysticercosis in rural areas of Yucatan, Mexico. Vet Parasitol. 1998;79:165-80.

108 Sahu PS, Parija SC, Narayan SK, Kumar D. Evaluation of an IgG-ELISA strategy using Taenia solium metacestode somatic and excretory-secretory antigens for diagnosis of neurocysticercosis revealing biological stage of the larvae. Acta Trop. 2009; 110:38-45.

109 Aguilar-Rebolledo F, Meza-Lucas A, Torres J, Cedillo-Rivera R, Enciso A, Garcia RC, et al. Evaluation of the enzymelinked immunoelectrotransfer blot assay for diagnosis of neurocysticercosis in children. J Child Neurol. 2002;17:416-20.

110 Barcelos IS, Ferreira MS, Moura LP, Biondi GF, Costa-Cruz JM. Use of the paired samples (cerebrospinal fluid and serum) in immunodiagnostic of active and inactive human neurocysticercosis. Mem Inst Oswaldo Cruz. 2005;100:427-9.

111 Cho SY, Kim SI, Kang SY, Choi DY, Suk JS, Choi KS, et al. Evaluation of enzyme-linked immunosorbent assay in serological diagnosis of human neurocysticercosis using paired samples of serum and cerebrospinal fluid. Kisaengch'unghak Chapchi. 1986;24:25-41.

112 Braga FM, dos Reis-Filho JB, de Camargo-Lima JG. [Ventriculo-lumbar gradient of concentration of total cerebrospinal fluid proteins: 1 - mechanisms of origin]. Arq Neuro-psiquiatr. 1983;41:254-65.

113 Torres-Corzo JG, Tapia-Perez JH, Sanchez-Aguilar M, Della Vecchia RR, Chalita Williams JC, Cerda-Gutierrez R. Comparison of cerebrospinal fluid obtained by ventricular endoscopy and by lumbar puncture in patients with hydrocephalus secondary to neurocysticercosis. Surg Neurol. 2009; 71:376-9.

114 Miller B, Goldberg MA, Heiner D, Myers A, Goldberg A. A new immunologic test for CNS cysticercosis. Neurology. 1984;34:695-7.

115 Miller BL, Staugaitis SM, Tourtellotte WW, Shapshak P, Goldberg M, Heiner D, et al. Intra-blood-brain barrier IgG synthesis in cerebral cysticercosis. Arch Neurol. 1985;42:782-

116 Livramento JA. [A cerebrospinal fluid syndrome in neurocysticercosis]. Arq Neuro-psiquiatr. 1987;45:261-75.

117 Estanol B, Juarez H, Irigoyen Mdel C, Gonzalez-Barranco D, Corona T. Humoral immune response in patients with cerebral parenchymal cysticercosis treated with praziquantel. J Neurol Neurosurg Psychiatry. 1989;52:254-7.

118 Estanol Vidal B, Diaz Granados J, Corona Vazquez T. [Integrity of the blood-brain barrier and intrathecal synthesis of $\mathrm{IgG}$ in parenchymatous and subarachnoid cerebral cysticercosis]. Rev Invest Clin. 1989;41:327-30.

119 Machado LR, Livramento JA, Vaz AJ, Bueno EC, Mielli SR, Bastouly $\mathrm{V}$, et al. IgG intrathecal synthesis and specific antibody index in patients with neurocysticercosis. Arq Neuro-psiquiatr. 2002;60:395-9.

120 Jafri HS, Torrico F, Noh JC, Bryan RT, Balderrama F, Pilcher JB, et al. Application of the enzyme-linked immunoelectrotransfer blot to filter paper blood spots to estimate seroprevalence of cysticercosis in Bolivia. Am J Trop Med Hyg. 1998;58:313-5.
121 Fleury A, Bouteille B, Garcia E, Marquez C, Preux PM, Escobedo F, et al. Neurocysticercosis: validity of ELISA after storage of whole blood and cerebrospinal fluid on paper. Trop Med Int Health. 2001;6:688-93.

122 Wang LN, Ge LY, Miao F, Yu ZH, Liu YB, Zhen TM, et al. [Application of EITB in immunodiagnosis of cysticercosis]. Chin J Parasitol Parasitic Dis. 2004;22:98-100.

123 Ishida MM, Almeida MS, Espindola NM, Iha A, Pereira DA, Souza JG, et al. Seroepidemiological study of human cysticercosis with blood samples collected on filter paper, in Lages, State of Santa Catarina, Brazil, 2004-2005. Rev Soc Brasil Med Trop. 2011;44:339-43.

124 Handali S, Rodriguez S, Noh J, Gonzalez AE, Garcia HH, Gilman RH, et al. A simple method for collecting measured whole blood with quantitative recovery of antibody activities for serological surveys. J Immunol Methods. 2007;320:164-71.

125 Atluri SR, Singhi P, Khandelwal N, Malla N. Neurocysticercosis immunodiagnosis using Taenia solium cysticerci crude soluble extract, excretory secretory and lower molecular mass antigens in serum and urine samples of Indian children. Acta Trop. 2009;110:22-7.

126 Atluri SR, Singhi P, Khandelwal N, Malla N. Evaluation of excretory secretory and $10-30 \mathrm{kDa}$ antigens of Taenia solium Cysticerci by EITB assay for the diagnosis of neurocysticercosis. Parasite Immunol. 2009;31:151-5.

127 Acosta E. Antibodies to the metacestode of Taenia solium in the saliva from patients with neurocysticercosis. J Clin Lab Anal. 1990;4:90-4

128 Sahu PS, Parija SC, Sahu PK. Tear IgA-ELISA: a novel and sensitive method for diagnosis of ophthalmic cysticercosis. Acta Trop. 2008;106:168-74.

129 Estrada JJ, Kuhn RE. Immunochemical detection of antigens of larval Taenia solium and anti-larval antibodies in the cerebrospinal fluid of patients with neurocysticercosis. J Neurol Sci. 1985;71:39-48.

130 Tellez-Giron E, Ramos MC, Dufour L, Alvarez P, Montante M. Detection of Cysticercus cellulosae antigens in cerebrospinal fluid by dot enzyme-linked immunosorbent assay (DotELISA) and standard ELISA. Am J Trop Med Hyg. 1987:37:169-73

131 Estrada JJ, Estrada JA, Kuhn RE. Identification of Taenia solium antigens in cerebrospinal fluid and larval antigens from patients with neurocysticercosis. Am J Trop Med Hyg. 1989;41:50-5.

132 Choromanski L, Estrada JJ, Kuhn RE. Detection of antigens of larval Taenia solium in the cerebrospinal fluid of patients with the use of HPLC and ELISA. J Parasitol. 1990;76:69-73.

133 Harrison LJ, Joshua GW, Wright SH, Parkhouse RM. Specific detection of circulating surface/secreted glycoproteins of viable cysticerci in Taenia saginata cysticercosis. Parasite Immunol. 1989;11:351-70.

134 Brandt JR, Geerts S, De Deken R, Kumar V, Ceulemans F, Brijs L, et al. A monoclonal antibody-based ELISA for the detection of circulating excretory-secretory antigens in Taenia saginata cysticercosis. Int J Parasitol. 1992;22:471-7.

135 Draelants E, Brandt JR, Kumar V, Geerts S. Characterization of epitopes on excretory-secretory antigens of Taenia saginata metacestodes recognized by monoclonal antibodies with immunodiagnostic potential. Parasite Immunol. 1995;17:11926.

136 Van Kerckhoven I, Vansteenkiste W, Claes M, Geerts S, Brandt J. Improved detection of circulating antigen in cattle infected with Taenia saginata metacestodes. Vet Parasitol. 1998:76:269-74.

137 Chen JP, Zhang XY, Tan W, Liu MF, Liu GL, Hu YX. [Determination of circulating antigen in cysticercosis patients using McAb-based ELISA]. Chin J Parasitol Parasitic Dis. 1991;9:122-5.

138 Wang CY, Zhang HH, Ge LY. A MAb-based ELISA for detecting circulating antigen in CSF of patients with neurocysticercosis. Hybridoma. 1992;11:825-7.

139 Wang CY, Li QS, Zhang HH, Su JJ, Zhang JJ, Li H, et al. [Detection of CAg in CSF of 231 cerebral cysticercosis patients]. Chin J Parasitol Parasitic Dis. 1993;11:276-8.

140 Harmsen MM, De Haard HJ. Properties, production, and applications of camelid single-domain antibody fragments. Appl Microbiol Biotechnol. 2007;77:13-22.

141 Deckers N, Saerens D, Kanobana K, Conrath K, Victor B, Wernery $\mathrm{U}$, et al. Nanobodies, a promising tool for speciesspecific diagnosis of Taenia solium cysticercosis. Int $\mathbf{J}$ Parasitol. 2009;39:625-33. 
142 Garcia HH, Parkhouse RM, Gilman RH, Montenegro T, Bernal T, Martinez SM, et al. Serum antigen detection in the diagnosis, treatment, and follow-up of neurocysticercosis patients. Trans R Soc Trop Med Hyg. 2000;94:673-6.

143 Fleury A, Hernandez M, Fragoso G, Parkhouse RM, Harrison LJ, Sciutto E. Detection of secreted cysticercal antigen: a useful tool in the diagnosis of inflammatory neurocysticercosis. Trans $\mathrm{R}$ Soc Trop Med Hyg. 2003;97:542-6.

144 Deckers N, Kanobana K, Silva M, Gonzalez AE, Garcia HH, Gilman RH, et al. Serological responses in porcine cysticercosis: a link with the parasitological outcome of infection. Int $\mathrm{J}$ Parasitol. 2008;38:1191-8.

145 Bobes RJ, Hernandez M, Marquez C, Fragoso G, Garcia E, Parkhouse RM, et al. Subarachnoidal and intraventricular human neurocysticercosis: application of an antigen detection assay for the diagnosis and follow-up. Trop Med Int Health. 2006;11:943-50.

146 Fleury A, Hernandez M, Avila M, Cardenas G, Bobes RJ, Huerta M, et al. Detection of HP10 antigen in serum for diagnosis and follow-up of subarachnoidal and intraventricular human neurocysticercosis. J Neurol Neurosurg Psychiatry. 2007;78:970-4.

147 Garcia HH, Dorny P, Castillo Y, Pretell EJ, Rodriguez S, Mija L, et al. Circulating antigen levels follow post-treatment evolution of subarachnoid neurocysticercosis. J Neuroparasitol. 2010;1:1-3.

148 Garcia HH, Harrison LJ, Parkhouse RM, Montenegro T, Martinez SM, Tsang VC, et al. A specific antigen-detection ELISA for the diagnosis of human neurocysticercosis. The Cysticercosis Working Group in Peru. Trans R Soc Trop Med Hyg. 1998;92:411-4.

149 Nguekam, Zoli AP, Ongolo-Zogo P, Dorny P, Brandt J, Geerts S. Follow-up of neurocysticercosis patients after treatment using an antigen detection ELISA. Parasite (Paris, France). 2003;10:65-8.

150 Alexander AM, Prabhakaran V, Rajshekhar V, Muliyil J, Dorny P. Long-term clinical evaluation of asymptomatic subjects positive for circulating Taenia solium antigens. Trans R Soc Trop Med Hyg. 2010;104:809-10.

151 Aranda-Alvarez JG, Tapia-Romero R, Alcantara-Anguiano I, Meza-Lucas A, Mata-Ruiz O, Celis-Quintal G, et al. Human cysticercosis: risk factors associated with circulating serum antigens in an open community of San Luis Potosi, Mexico. Ann Trop Med Parasitol. 1995;89:689-92.

152 Correa D, Sarti E, Tapia-Romero R, Rico R, AlcantaraAnguiano I, Salgado A, et al. Antigens and antibodies in sera from human cases of epilepsy or taeniasis from an area of Mexico where Taenia solium cysticercosis is endemic. Ann Trop Med Parasitol. 1999;93:69-74.

153 Rodriguez-Hidalgo R, Benitez-Ortiz W, Praet N, Saa LR, Vercruysse $\mathrm{J}$, Brandt $\mathrm{J}$, et al. Taeniasis-cysticercosis in Southern Ecuador: assessment of infection status using multiple laboratory diagnostic tools. Mem Inst Oswaldo Cruz. 2006;101:779-82.

154 Krecek RC, Michael LM, Schantz PM, Ntanjana L, Smith MF, Dorny $\mathrm{P}$, et al. Prevalence of Taenia solium cysticercosis in swine from a community-based study in 21 villages of the Eastern Cape Province, South Africa. Vet Parasitol. 2008; 154:38-47.

155 Newell E, Vyungimana F, Geerts S, Van Kerckhoven I, Tsang VC, Engels D. Prevalence of cysticercosis in epileptics and members of their families in Burundi. Trans R Soc Trop Med Hyg. 1997;91:389-91.

156 Lin X, Li G, Huo H, Xu F, Li Q, Zhao Z. [Detection of circulating antigen in serum and cerebrospinal fluid fo diagnosis of cerebral cysticercosis]. Chin J Parasitol Parasitic Dis. $1999 ; 17: 146-8$

157 Flisser A, Plancarte A, Correa D, Rodriguez-Del-Rosal E, Feldman M, Sandoval M, et al. New approaches in the diagnosis of Taenia solium cysticercosis and taeniasis. Ann Parasitol Hum Comp. 1990;65(Suppl 1):95-8.

158 Freilij HL, Corral RS, Katzin AM, Grinstein S. Antigenuria in infants with acute and congenital Chagas' disease. J Clin Microbiol. 1987;25:133-7.

159 Zheng HJ, Tao ZH, Reddy MV, Harinath BC, Piessens WF. Parasite antigens in sera and urine of patients with bancroftian and brugian filariasis detected by sandwich ELISA with monoclonal antibodies. Am J Trop Med Hyg. 1987;36:554-60.
160 Kremsner PG, de Jonge N, Simarro PP, Muhlschlegel F, Mir M, Sima FO, et al. Quantitative determination of circulating anodic and cathodic antigens in serum and urine of individuals infected with Schistosoma intercalatum. Trans R Soc Trop Med Hyg. 1993;87:167-9.

161 Parija SC, Ravinder PT, Rao KS. Detection of hydatid antigen in urine by countercurrent immunoelectrophoresis. J Clin Microbiol. 1997;35:1571-4

162 Parija M, Biswas R, Harish BN, Parija SC. Detection of specific cysticercus antigen in the urine for diagnosis of neurocysticercosis. Acta Trop. 2004;92:253-60.

163 Castillo Y, Rodriguez S, Garcia HH, Brandt J, Van Hul A, Silva M, et al. Urine antigen detection for the diagnosis of human neurocysticercosis. Am J Trop Med Hyg. 2009;80:37983.

164 Mwape KE, Praet N, Benitez-Ortiz W, Muma JB, Zulu G, Celi-Erazo M, et al. Field evaluation of urine antigen detection for diagnosis of Taenia solium cysticercosis. Trans R Soc Trop Med Hyg. 2011;105:574-8.

165 Rajshekhar V. Etiology and management of single small CT lesions in patients with seizures: understanding a controversy. Acta Neurol Scand. 1991;84:465-70.

166 Sethi PP, Wadia RS, Kiyawat DP, Ichaporia NR, Kothari SS, Sangle SA, et al. Ring or disc enhancing lesions in epilepsy in India. J Trop Med Hyg. 1994;97:347-53.

167 Kumar Garg R, Kumar Singh M, Misra S. Single-enhancing $\mathrm{CT}$ lesions in Indian patients with seizures: a review. Epil Res. 2000;38:91-104.

168 Del Brutto OH. Solitary cysticercus granuloma in Latin America. In: Rajshekhar V, Chandy MJ, editors. Solitary cysticercus granuloma: the disappearing lesion. Chennai: Orient Longman; 2000. p. 153-63.

169 Garg RK. Single enhancing computerized tomographydetected lesion in immunocompetent patients. Neurosurg Focus. 2002;12:e4

170 Carod-Artal FJ. [Tropical causes of epilepsy]. Rev Neurol. 2009;49:475-82.

171 Rajshekhar V, Oommen A. Utility of the cysticercus immunoblot in a patient with an atypical solitary cerebral cysticercus granuloma. Neurol India. 2001;49:75-7.

172 Garcia HH, Gonzalez AE, Rodriguez S, Tsang VC, Pretell EJ, Gonzales I, et al. Neurocysticercosis: unraveling the nature of the single cysticercal granuloma. Neurology. 2010;75:654-8.

173 Prabhakaran V, Rajshekhar V, Murrell KD, Oommen A. Conformation-sensitive immunoassays improve the serodiagnosis of solitary cysticercus granuloma in Indian patients. Trans R Soc Trop Med Hyg. 2007;101:570-7.

174 McManus DP. Molecular discrimination of taeniid cestodes. Parasitol Int. 2006;55(Suppl):S31-7.

175 Almeida CR, Ojopi EP, Nunes CM, Machado LR, Takayanagui OM, Livramento JA, et al. Taenia solium DNA is present in the cerebrospinal fluid of neurocysticercosis patients and can be used for diagnosis. Eur Arch Psychiatry Clin Neurosci. 2006;256:307-10.

176 Hernandez M, Gonzalez LM, Fleury A, Saenz B, Parkhouse RM, Harrison LJ, et al. Neurocysticercosis: detection of Taenia solium DNA in human cerebrospinal fluid using a semi-nested PCR based on HDP2. Ann Trop Med Parasitol. 2008;102:317-23.

177 Michelet L, Fleury A, Sciutto E, Kendjo E, Fragoso G, Paris $\mathrm{L}$, et al. Human neurocysticercosis: comparison of different diagnostic tests using cerebrospinal fluid. J Clin Microbiol. 2011;49:195-200.

178 Ramahefarisoa RM, Rakotondrazaka M, Jambou R, Carod JF. Comparison of ELISA and PCR assays for the diagnosis of porcine cysticercosis. Vet Parasitol. 2010;173:336-9.

179 Praet N, Rodriguez-Hidalgo R, Speybroeck N, Ahounou S, Benitez-Ortiz W, Berkvens D, et al. Infection with versus exposure to Taenia solium: what do serological test results tell us? Am J Trop Med Hyg. 2010;83:413-5.

180 Handali S, Klarman M, Gaspard AN, Dong XF, Laborde R, Noh $\mathrm{J}$, et al. Development and evaluation of a magnetic immunochromatographic test to detect Taenia solium, which causes taeniasis and neurocysticercosis in humans. Clin Vaccine Immunol. 2010;17:631-7

181 Sato MO, Yamasaki H, Sako Y, Nakao M, Nakaya K, Plancarte A, et al. Evaluation of tongue inspection and serology for diagnosis of Taenia solium cysticercosis in swine: usefulness of ELISA using purified glycoproteins and recombinant antigen. Vet Parasitol. 2003;111:309-22. 